\title{
Postfire Seeding and Plant Community Recovery in the Great Basin
}

\author{
S. M. Kulpa, ${ }^{1}$ E. A. Leger, ${ }^{2}$ E. K. Espeland, ${ }^{4}$ and E. M. Goergen ${ }^{3}$ \\ Authors are ${ }^{1}$ Botanist, US Fish and Wildlife Service, Reno, NV 89502, USA; ${ }^{2}$ Assistant Professor of Plant Ecology and ${ }^{3}$ Postdoctoral Researcher, \\ Department of Natural Resources and Environmental Science, University of Nevada, Reno, Reno, NV 89557, USA; and ${ }^{4}$ Research Ecologist, USDA-ARS \\ NPARL, Pest Management Research Unit, Sidney, MT 59270, USA.
}

\begin{abstract}
As wildland fire frequency increases around the globe, a better understanding of the patterns of plant community recovery in burned landscapes is needed to improve rehabilitation efforts. We measured establishment of seeded species, colonization of Bromus tectorum and other nonnative annual plants, and recovery of nonseeded native species in topographically distinct areas within five fires that burned Great Basin shrub-steppe communities in Elko County, Nevada. Plant density, frequency, and cover data were collected annually for 4 yr postfire. Vegetation composition varied among flat areas and north- and south-facing aspects, and changed over the course of the sampling period; recovery varied among sites. In general, B. tectorum densities were higher on south aspects, particularly 3 and 4 yr after fire, when densities increased dramatically relative to prefire conditions. Nonseeded native perennial grasses, forbs, and shrubs were abundant in three of the five fire sites, and were more likely to be present on north aspects and flat areas. Over time, nonseeded perennial grass densities remained relatively constant, and nonseeded forbs and shrubs increased. Seeded species were most likely to establish in flat areas, and the density of seeded perennial grasses, forbs, and shrubs decreased over time. Frequency and density measurements were highly correlated, especially for perennial species. Our results emphasize the value of considering site aspect and the potential for native regrowth when planning and monitoring restorations. For example, effective rehabilitation of south aspects may require the development of new restoration methods, whereas north aspects and flat areas in sites with a strong native component were not improved by the addition of seeded species, and may require weed control treatments, rather than reseeding, to improve recovery. Tailoring revegetation objectives, seed mixes, seeding rates, and monitoring efforts to conditions that vary within sites may lead to more cost effective and successful restoration.
\end{abstract}

\section{Resumen}

A medida que aumenta la frecuencia de los incendios en el mundo, se necesita entender mejor los patrones de recuperación de las comunidades vegetales en paisajes quemados para mejorar los esfuerzos de rehabilitación. Medimos el establecimiento de especies sembradas, colonización de Bromus tectorum y otras especies anuales no nativas y la recuperación de especies nativas no sembradas in áreas topográficamente distintas dentro de cinco comunidades de matorral y estepa quemas en la Great Basin en Elko, County en Nevada. Por cuatro años se colectaron datos de densidad, frecuencia y cobertura de plantas después del fuego. La composición vegetal vario entre las áreas planas, las exposiciones norte y sur y cambios sobre el curso del periodo de muestreo y recuperación entre sitios. En general, las densidades de B. tectorum fueron mayores en las exposiciones sur, principalmente tres y cuatro años después del fuego, cuando las densidades aumentaron drásticamente relativamente a la condición de pre-quema. Pastos, hierbas y arbustos perennes no sembrados fueron abundantes en tres de los cinco sitios y se presentaron en la exposición norte y áreas planas. A través del tiempo, las densidades de pastos perennes no sembrados permaneció relativamente constante mientras que las hierbas y arbustos no sembrados aumentaron. Las especies sembradas se establecieron en áreas planas y la densidad de pastos, hierbas y arbustos perennes sembrados disminuyo a través del tiempo. Las medidas de frecuencia y densidad estuvieron altamente correlacionadas especialmente para especies perennes. Nuestros resultados enfatizan el valor de considerar aspecto del sitio y el potencial de rebrote de nativas cuando se planea y monitorea restauración. Por ejemplo, la rehabilitación efectiva de exposiciones sur podría requerir el desarrollo de nuevos métodos de restauración mientras que, exposiciones norte y áreas planas en sitios con fuerte componente de nativas no fueron mejoradas agregándole especies sembradas y podría necesitar control de malezas en lugar de resiembra para mejorar la recuperación. Los objetivos diseñados a la medida, mezcla de semillas, porcentaje de plántulas y esfuerzos de monitoreo en condiciones que varían entre sitios podría ofrecer restauración económicamente efectiva y exitosa.

Key Words: aspect, Bromus tectorum, density, emergency fire rehabilitation, frequency, restoration

\section{INTRODUCTION}

This research was funded by the University of Nevada, Reno, the Nevada Agricultural Experiment Station, and USDA-Hatch.

At the time of the research, Kulpa was a research assistant, Department of Natural Resources and Environmental Science, University of Nevada, Reno, Reno, NV 89557, USA.

Correspondence: Sarah M. Kulpa, US Fish and Wildlife Service, 1340 Financial Blvd, Suite 234,

Reno, NV 89502, USA. Email: smkulpa@gmail.com

Manuscript received 8 March 2011; manuscript accepted 28 November 2011.
Wildland fires around the globe are increasing in frequency and scale compared to historic norms (Westerling et al. 2006). Contributing factors include increased temperature and altered precipitation associated with climate change (Westerling et al. 2006; Marlon et al. 2009). Another contributing factor is ecosystem shifts from diverse, native plant communities to 
those invaded by nonnative species, including highly flammable annual grasses (D’Antonio and Vitousek 1992; DiTomaso 2000; Milton 2004). Although fires are a normal disturbance in rangeland systems, recent increases in fire size and frequency in the Great Basin are slowing or preventing native plant community recovery (Koniak 1985; Miller and Rose 1999; Brooks and Pyke 2002). After fire, sagebrush steppe communities without a well-established perennial understory of grasses and forbs are susceptible to invasion, and can be converted to near monocultures of the invasive annual grass Bromus tectorum L. (cheatgrass), because of its strong competitive effects on the seedlings of most native species (Young and Evans 1978; Young and Allen 1997; Chambers et al. 2007).

Federal agencies, such as the Bureau of Land Management (BLM), conduct postfire rehabilitation through the Emergency Stabilization and Rehabilitation (ES\&R) program (US Department of the Interior, Bureau of Land Management [USDI BLM] 2007). One way that ES\&R programs are implemented is through the seeding of burned areas with native and nonnative species by rangeland drill and/or aerial seeding in the fall or winter following wildfire. The primary objectives of these seedings are 1) to reduce the postfire dominance of nonnative annual grasses such as $B$. tectorum; 2) to minimize the probability of recurrent fire; and 3) to produce desirable vegetation characteristics (Knutson et al. 2009). Despite the large scale of these rehabilitation efforts, there are few available data on the success of ES\&R projects prior to 1999 (Knutson et al. 2009), and data are synthesized only rarely (e.g., Pyke and McArthur 2002; Eiswerth et al. 2009).

To date, we know that results of revegetation efforts in the Great Basin rangelands vary widely. Some fires or areas within fires show substantial establishment of seeded species, others show natural recovery of predominantly nonseeded native species, and others become dominated by annual grasses despite seeding efforts (West and Hassan 1985; Ratzlaff and Anderson 1995; Robichaud et al. 2000; Thompson et al. 2006; Shinneman and Baker 2009; Wirth and Pyke 2009; James and Svejcar 2010). Site-specific barriers to seedling establishment include variation in rainfall and temperature and the presence of invasive species, and more general barriers to establishment include the availability of species and varieties with appropriate genetic characteristics to grow well in the climate regime, microclimate, soil condition, and competitive environment in which they are planted (Call and Roundy 1991; Allen 1995; Humphrey and Schupp 2001). Additional factors that affect postfire revegetation success include seeding rate (Burton et al. 2006; Eiswerth and Shonkwiler 2006) and seeding methodology (Bleak et al. 1965; Montalvo et al. 2002).

Effects of topographical factors such as slope or aspect on restoration success have not been widely studied, though these factors are likely to affect recovery. North- and south-facing aspects differ in microclimatic conditions that affect both vegetation and soil nutrients (Kutiel 1992; Sternberg and Shoshany 2001). Long-term soil weathering and erosion processes are usually accelerated on south-facing aspects due to warmer temperatures, increased freeze-thaw cycles, and/or increased wetting and drying cycles (Rech et al. 2001), which result in different soil properties and plant communities on north- and south-facing aspects (Bochet and Garcia-Fayos 2004; Bennie et al. 2006; Gong et al. 2007). The resulting differences in both abiotic conditions and plant communities among variable slopes and aspects can influence postfire vegetation recovery.

Many different monitoring techniques are used to assess community recovery. For example, within the BLM, offices choose among a variety of monitoring methods described in seven different manuals (reviewed in Wirth and Pyke 2007). Different sampling methods have trade-offs between the amount of time required and precision (Abella and Covington 2004), and may result in different interpretations of community trajectory and rehabilitation success after fire (Korb et al. 2003). Often the method chosen is based on time and money limitations, as funding for the monitoring of seeded sites through the ES\&R program is only provided for $3 \mathrm{yr}$ after fire (Eiswerth et al. 2009). Using methods that are consistent among observers and not labor intensive might allow monitoring of larger areas for the same cost. For example, frequency measurements can be substantially faster than density counts (Vogel and Masters 2001). Though results are always mathematically related, the degree to which density and frequency measurements detect the same vegetation patterns depends on the specific biology of plants being monitored, including factors such as plant growth form, natural density, and plant dispersion in the wild (Bonham 1989). Quantifying the degree to which frequency and density measurements correlate among the types of vegetation present in postfire communities would allow managers to make informed decisions about how best to monitor community recovery.

The goals of this study were to describe community recovery for $4 \mathrm{yr}$ postfire, as well as to determine the relative effectiveness of two monitoring methods. First, we quantified how invasive species, seeded species, nonseeded native plants, litter, and bare ground changed over time, and asked how vegetation patterns differed by aspect and among sites. Second, we compared the results of frequency measurements with those of density counts, and quantified the agreement of these measures among monitored plant groups. Finally, we discuss how our data can be used by managers and suggest further research based on our results.

\section{METHODS}

\section{Site Selection}

Five sites that burned in Elko County, Nevada, in 2006 were selected for monitoring (Fig. 1). The Basco, East Humboldt, East Suzie, Mudd, and Sneekee fires were started on July 26, August 20, June 25, August 23, and June 26, 2006, respectively. The areas of the Basco, Mudd, and Sneekee fires had prefire communities dominated by sagebrush, the prefire community of East Humboldt contained Juniperus occidentalis Hook. (western juniper) and Artemisia sp. (sagebrush), and the prefire community of East Suzie was dominated by B. tectorum and Onopordum acanthium L. (scotch thistle) (T. Warren, personal communication, June 2009). Soils at all sites are sandy clay loams (Table 1). Soil analysis conducted in these areas confirmed these textural components, and documented increased silt content in flat areas and decreased plant available $\mathrm{N}$ on north aspects (Kulpa 2010).

Sites were drill and/or aerial seeded by the BLM with perennial grasses, forbs, and shrubs during the winter of 2006/ 


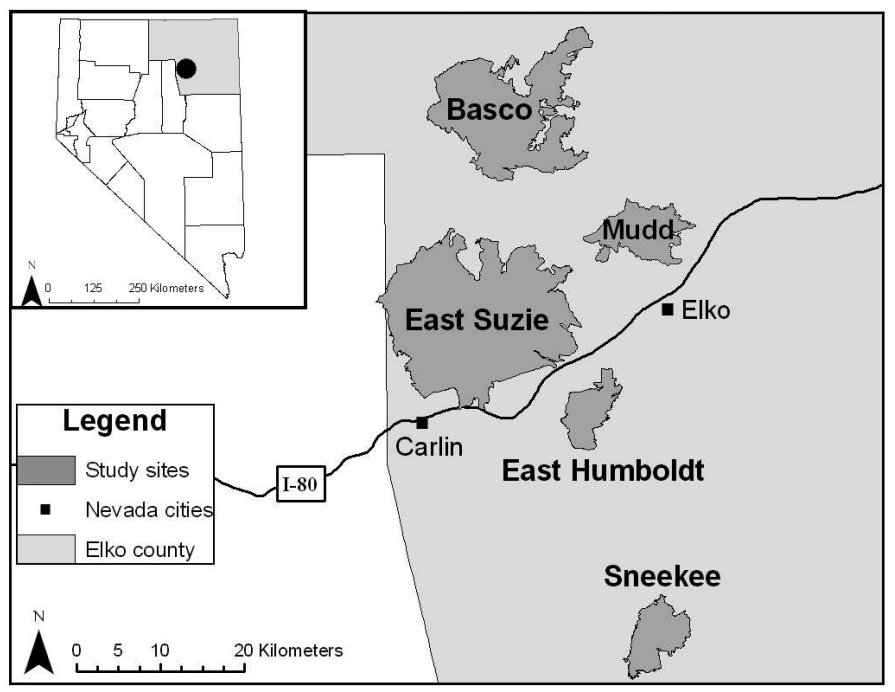

Figure 1. Fire boundaries and locations of five monitored fire sites in Elko County, NV that burned in 2006. Inset is a map of Nevada counties.

2007, with seed mixes chosen by the BLM based on site characteristics, and seeded at recommended rates. Seed mixes were primarily native species except for the East Humboldt site, which was seeded with nonnative species. For the purpose of this study, we monitored only portions of the sites that were drill seeded. Burned areas were closed to livestock grazing through 2009.

\section{Monitoring}

Elko BLM district ES\&R defines successful treatment as those which have at least three seeded plants $\mathrm{m}^{-2}$ firmly rooted in the ground within $3 \mathrm{yr}$ of the treatment application ( $\mathrm{T}$. Warren, personal communication, December 2009), and we designed our monitoring to assess whether seeded areas met this objective, as well as to determine how well results from less time-consuming frequency methods agreed with density counts. Sites were surveyed annually (from 2007-2010) over a 5-d period each June. At each selected fire site, one flat area $\left(0-2^{\circ}\right.$ slope), two north, and two south slope aspects were sampled, with landscape topography and extent of seeding determining the size of the sampled area (Table 1). Sampling transects were placed perpendicular to drill rows in flat areas or running up slopes. Slope was measured with the use of a clinometer at each location (Table 1). A total of five transects were placed in each flat area and three transects were placed on each slope. Transects were of variable length among study sites, but were consistent within a site from year to year, with starting locations selected with a stratified random method. More transects were placed in flat areas, as these were generally larger than slopes (Table 1). Three (on slopes) or five (on flat areas) $1 \times 1 \mathrm{~m}$ quadrats were placed systematically along each transect, every 2-10 m, depending on the size of sampled area. In each quadrat, we collected density and nested frequency data. Point cover data were collected at each of the four quadrat corners, where we noted which type of vegetation, ground cover, or bare ground was touching the edge of the quadrat. Nested frequency data were recorded in four size classes by noting the smallest quadrat size in which a species category was present (either $0.1 \times 0.1 \mathrm{~m}, 0.5 \times 0.5 \mathrm{~m}$, $1 \times 0.5 \mathrm{~m}$, or $1 \times 1 \mathrm{~m})$. This nested approach allows the selection of the most appropriate size category for analysis to be made after the data are collected, because quadrats are all nested within each other (e.g., a species present in the smallest quadrat is also present in all four larger ones, Elzinga et al. 1998).

Plant data were collected by vegetation categories, except for B. tectorum, which was monitored at the species level. Categories for density and frequency data included $B$. tectorum, other annual species (primarily nonnative forbs), dead shrub stems (Table 1, to infer prefire condition), seeded and nonseeded shrubs, perennial grasses, and perennial forbs.

Table 1. Characteristics of five fire sites in Elko County, NV, including size of sampling area (averaged between the two north and south aspect areas), for flat areas $(\mathrm{F})$, north $(\mathrm{N})$, and south aspects $(\mathrm{S})$; slope of north and south aspects; average frequency of dead shrub stems in a $1 \times 1 \mathrm{~m}$ quadrat the first year postfire; seeded species, ${ }^{1}$ and soil series associations. A dash indicates a component not seeded at a particular site. Bolded species are nonnative, and species marked with an asterisk are native to North America, but not naturally found in Nevada.

\begin{tabular}{|c|c|c|c|c|c|c|}
\hline & & Basco & East Humboldt & East Suzie & Mudd & Sneekee \\
\hline \multirow[t]{3}{*}{ Area surveyed } & $\mathrm{F}$ & $26216 \mathrm{~m}^{-2}$ & $1375 m^{-2}$ & $15145 \mathrm{~m}^{-2}$ & $4642 \mathrm{~m}^{-2}$ & $5800 \mathrm{~m}^{-2}$ \\
\hline & N & $1521 \mathrm{~m}^{-2}$ & $725 \mathrm{~m}^{-2}$ & $727 \mathrm{~m}^{-2}$ & $950 \mathrm{~m}^{-2}$ & $2048 \mathrm{~m}^{-2}$ \\
\hline & S & $1791 \mathrm{~m}^{-2}$ & $634 \mathrm{~m}^{-2}$ & $964 m^{-2}$ & $1062 \mathrm{~m}^{-2}$ & $966 \mathrm{~m}^{-2}$ \\
\hline \multirow[t]{2}{*}{ Slope } & $\mathrm{N}$ & $11^{\circ}, 14^{\circ}$ & $5^{\circ}, 8^{\circ}$ & $5^{\circ}, 6^{\circ}$ & $9^{\circ}, 10^{\circ}$ & $15^{\circ}, 19^{\circ}$ \\
\hline & S & $10^{\circ}, 11^{\circ}$ & $7^{\circ}, 9^{\circ}$ & $12^{\circ}, 13^{\circ}$ & $8^{\circ}, 10^{\circ}$ & $10^{\circ}, 14^{\circ}$ \\
\hline \multirow{3}{*}{$\begin{array}{l}\text { Dead shrub stem } \\
\text { frequency }\end{array}$} & $\mathrm{F}$ & 53.3 & 51.9 & 58.7 & 22.2 & 60.0 \\
\hline & $\mathrm{N}$ & 57.4 & 44.4 & 20.4 & 27.8 & 51.9 \\
\hline & $S$ & 37.0 & 48.2 & 20.4 & 18.5 & 44.4 \\
\hline \multirow[t]{3}{*}{ Seeded species } & Shrub & ARTRW & - & - & ARTRW, BAPR & ARTRW \\
\hline & Perennial grass & $\begin{array}{l}\text { ELLA, LECI, POSE, } \\
\text { PSSP }\end{array}$ & AGCR, AGFR, PSJU & $\begin{array}{l}\text { ACHY, ELWA*, POSE, } \\
\text { PSSP }\end{array}$ & $\begin{array}{l}\text { ACHY, AGCR, ELWA*, } \\
\text { PSJU, PSSP }\end{array}$ & $\begin{array}{l}\text { ACHY, ELLA, POSE, } \\
\text { PSSP }\end{array}$ \\
\hline & Perennial forb & ACMI & - & LIPE & ACMI, MESA & - \\
\hline Soil series associations & & Stampede-Donna-Bilbo & Enko-Rad & Bloor-Connel-Kelk & Donna-Stampede-Gance & Wieland-Enko \\
\hline
\end{tabular}

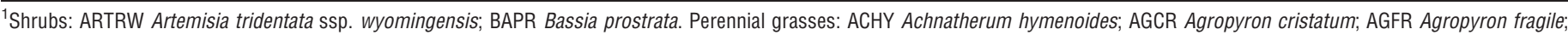
ELLA Elymus lanceolatus; ELWA Elymus wawawaiensis; LECI Leymus cinereus; POSE Poa secunda; PSJU Psathyrostachys juncea; PSSP Pseudoroegneria spicata. Perennial forbs: ACMI Achillea millefolium; LIPE. Linum perenne; MESA Medicago sativa. 
Table 2. Results from ANOVA comparing the density of seeded and nonseeded perennial species, Bromus tectorum, and other annuals among aspects and sites over a 4-yr survey period (2007-2010) in Elko County, Nevada, with significant $P$ values highlighted in bold.

\begin{tabular}{|c|c|c|c|c|c|c|c|c|c|c|c|c|c|c|}
\hline \multirow[b]{2}{*}{ Category } & \multicolumn{2}{|c|}{ Year } & \multicolumn{2}{|c|}{ Aspect } & \multicolumn{2}{|c|}{ Site } & \multicolumn{2}{|c|}{ Aspect $\times$ year } & \multicolumn{2}{|c|}{ Aspect $\times$ site } & \multicolumn{2}{|c|}{ Year $\times$ site } & \multicolumn{2}{|c|}{ Year $\times$ site $\times$ aspect } \\
\hline & $F$ & $P$ & $F$ & $P$ & $F$ & $P$ & $F$ & $P$ & $F$ & $P$ & $F$ & $P$ & $F$ & $P$ \\
\hline Seeded species $^{1}$ & 10.8 & $<0.0001$ & 2.6 & 0.1303 & 2.7 & 0.0947 & 3.7 & 0.0017 & 2.0 & 0.1153 & 9.6 & $<0.0001$ & 1.8 & 0.0084 \\
\hline Nonseeded native species ${ }^{1}$ & 14.4 & $<0.0001$ & 16.0 & 0.0011 & 15.6 & 0.0010 & 3.3 & 0.0040 & 3.4 & 0.0878 & 4.2 & $<0.0001$ & 3.1 & $<0.0001$ \\
\hline B. tectorum & 77.0 & $<0.0001$ & 18.7 & 0.0013 & 19.8 & 0.0005 & 10.7 & $<0.0001$ & 3.7 & 0.0442 & 13.3 & $<0.0001$ & 3.6 & $<0.0001$ \\
\hline Other annuals & 28.1 & $<0.0001$ & 10.0 & 0.0105 & 1.2 & 0.4115 & 3.3 & 0.0043 & 4.2 & 0.0380 & 2.7 & 0.0018 & 1.7 & 0.0294 \\
\hline
\end{tabular}

${ }^{1}$ Analysis conducted on summed density of all perennial grasses, perennial forbs, and shrubs.

Identification of seeded grass, nonseeded grass, and forb species was achieved with the use of the list of seeded species at each site (Table 1) and by identifying seedlings by species within the obvious drill row. Drill rows were obvious in 2007 and 2008, but became more difficult to see as plants grew larger and rows began to fade. Morphological differences between commercially available seeds and local genotypes allowed us to determine whether grasses and forbs were seeded or nonseeded natives, even after the drill rows had faded. By 2010, because of low establishment of seeded shrubs and obscured drill rows, it was no longer possible to distinguish them from nonseeded shrubs with certainty, so data are not presented for this category in 2010. Individual plants were distinguished with a distance rule: Any plant that was separated from another by $1.5 \mathrm{~cm}$ was counted as a separate individual. Density counts of most categories were taken in the entire $1 \times 1 \mathrm{~m}$ quadrat, although $B$. tectorum and other annual plant densities were counted in $0.1 \times 0.1 \mathrm{~m}$ or $0.5 \times 0.5 \mathrm{~m}$ quadrats in order to decrease observer error and increase accuracy of counts for these very common plants. For all analyses, density was scaled up to a $1 \times 1 \mathrm{~m}$ area. Cover data were collected for the same plant categories, as well as for litter, rock $(>5 \mathrm{~mm}$ diameter $)$, and bare ground $(<5 \mathrm{~mm}$ diameter).

\section{Precipitation}

The 30-yr average precipitation (1980-2010) and precipitation from October 2006 through October 2010 was compiled from the Elko WB Airport station in Elko, Nevada, with the use of the Western Regional Climate Center data. ${ }^{1}$ This is the closest station with a complete 30-yr record, located at $1533 \mathrm{~m}$ elevation and approximately $23.6 \mathrm{~km}$ southeast from Basco (elevation $1739 \mathrm{~m}$ ), $7.7 \mathrm{~km}$ northeast from East Humboldt (elevation $1564 \mathrm{~m}$ ), $23.8 \mathrm{~km}$ east from East Suzie (elevation $1535 \mathrm{~m}$ ), $8.5 \mathrm{~km}$ southwest from Mudd (elevation $1759 \mathrm{~m}$ ), and $35.8 \mathrm{~km}$ north from Sneekee (elevation $1648 \mathrm{~m}$ ). Thirtyyear average annual precipitation for the study area during the growing season (October-September) is $254 \mathrm{~mm}$. The area received 148, 192, 303, and $214 \mathrm{~mm}$ growing-season precipitation from 2006 through 2010, respectively.

\section{Data Analysis}

Analyses were conducted with the use of standard least squares in JMP version 8 statistical software (SAS Institute Inc., Cary, NC). Differences in density among aspects and sites and changes over time were compared with the use of ANOVA, and

${ }^{1}$ http://www.wrcc.dri.edu main effects for the analyses were year, aspect, and site, and all two- and three-way interactions. Additionally, individual sampling locations (nested within aspect and site) and transects (nested within year, aspect, site, and slope) were included in the model as random factors, with the use of the expected means squared (EMS) method for calculating significance. For brevity, full analysis of variance (ANOVA) results are presented for summed densities of seeded and nonseeded perennial grasses, forbs, and shrubs, and results from individual categories are presented in text and figures. Plant density of all vegetation categories in the final year of survey was analyzed with the use of a similar ANOVA model, differing in that "year," and its interactions were not included in the model. Significance of random factors (locations and transects) are not presented for brevity. Mean comparisons were performed with the use of Tukey's tests for multiple comparisons and results were considered significant at the $95 \%$ confidence level $(\alpha=0.05)$.

Quadrat size for the frequency analysis was selected based on the smallest quadrat in which species were present between $30 \%$ and $70 \%$ of the time (Elzinga et al. 1998), and the same quadrat size was used for analysis over the 4-yr study period. Average frequency of each categorical group was calculated for each transect, and changes in frequency among aspects, sites, and across years were analyzed as a continuous variable, with the use of a similar model format as the density analysis, except that transects were not included in the model. The agreement between density and frequency measures was analyzed by calculating the average density and frequency for each transect in every year, and Spearman's rank correlations between these two measurements were conducted for each category. Percent cover of each vegetation category and abiotic cover category was calculated for each transect (summed from all quadrats along each transect), and changes in cover among aspects, sites, and across years was analyzed with the use of the same model as frequency data. The presentation of cover data is limited to the main effects of aspect and changes in cover over time, as analytical results from these measurements for vegetation categories were in agreement with density and frequency analysis.

\section{RESULTS}

Vegetation composition differed among aspects and changed over the study period, and recovery patterns differed between sites. There were significant three-way interactions between sampling year, aspect, and site for density of every category (Table 2). We present these interactions first, and then present 
Seeded species

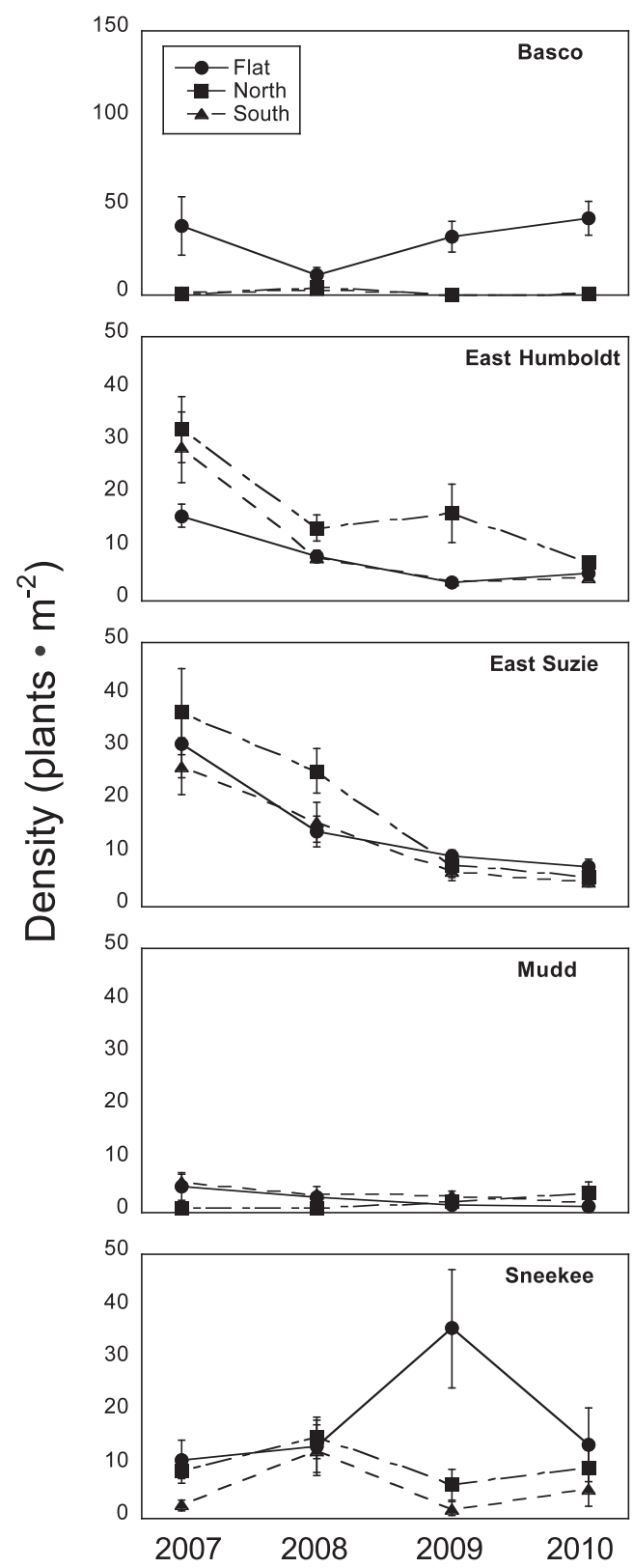

Non-seeded species
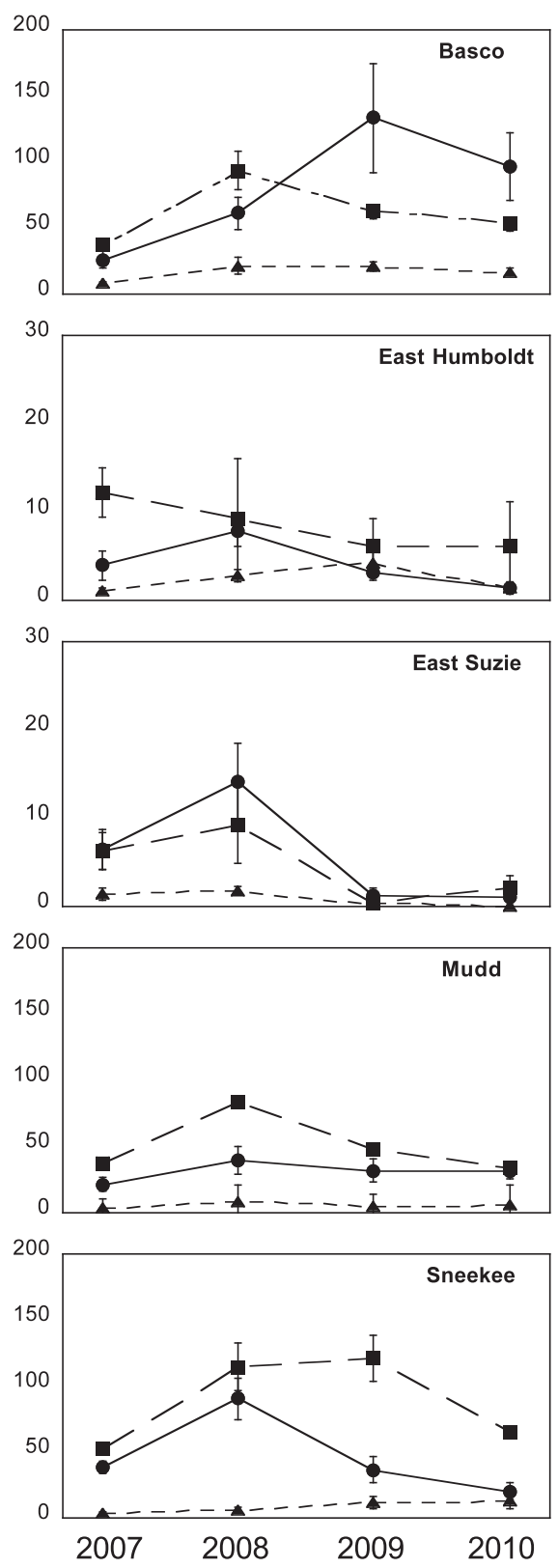

B. tectorum
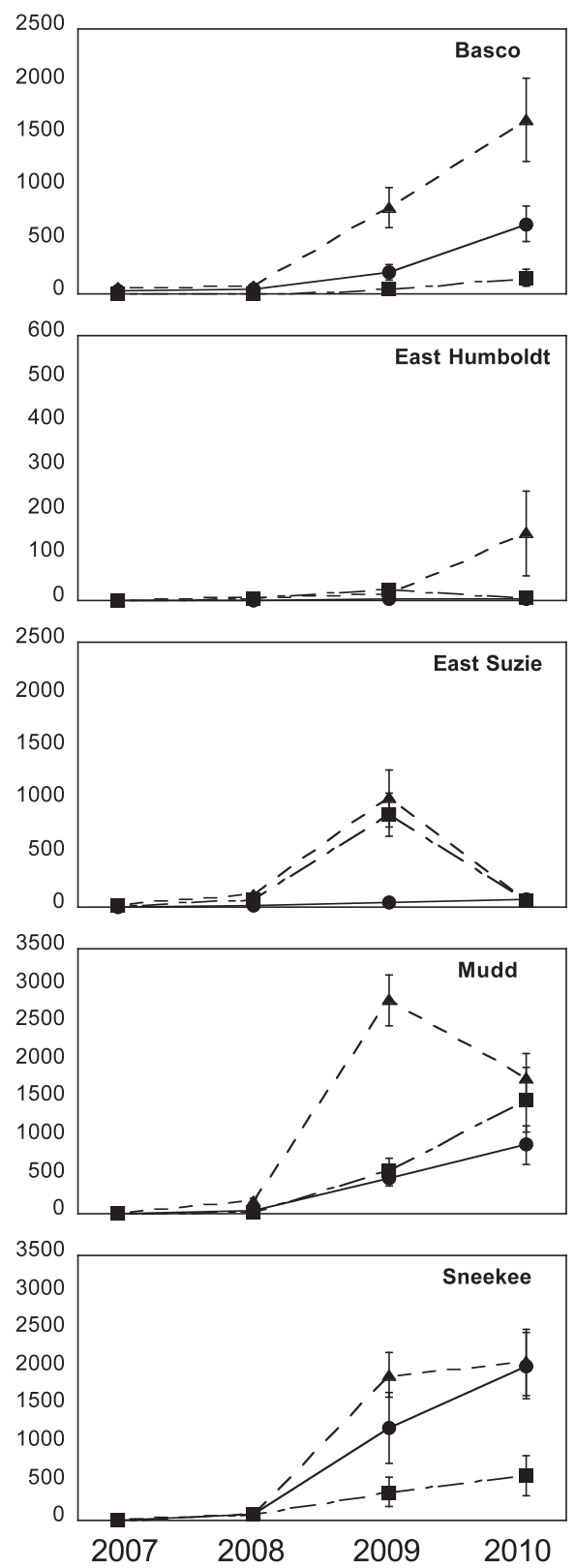

Figure 2. Density of seeded species, nonseeded species, and Bromus tectorum at each of five sites, displayed by aspect and over time. Note changes in $Y$-axis scale between sites.

main effects and the year by aspect interactions to show trends in fire recovery in these five sites over time.

\section{Vegetation Recovery Over Time by Site and Aspect}

Sites differed in their recovery process over time and by aspect (year $\times$ site $\times$ aspect interactions, Table 2$)$. At Basco and Sneekee, densities of seeded species were highest in flat areas (Basco) or flat areas and north slopes (Sneekee), with patchy establishment in the flat areas at the Sneekee site, leading to large variation in density counts (Fig. 2). Seeded species densities were highest at these two sites because of the seeding of the rhizomatous species Elymus lanceolatus (Scribn. \& J.G. Sm.) Gould (thickspike wheatgrass, Table 1). At the East Humboldt and East Suzie site, densities of seeded species were highest in 2007 and declined over time, with overall densities highest on north slopes (Fig. 2). At the Mudd site, seeded species had low densities on all aspects, which remained constant over time.

Sites also differed in their amount of nonseeded species on different aspects over time (Table 2). Basco, Mudd, and Sneekee, which had relatively high densities of nonseeded species, showed the highest densities of nonseeded species on north slopes and/or flat areas. These densities were highest in 2008 and 2009, but showed reductions by 2010. Although East Humboldt and East Suzie had very few nonseeded species, they were still most common on north slopes and flat areas. At East Suzie, these nonseeded species declined over time, whereas at East Humboldt, nonseeded species maintained consistently low 
Table 3. The density (plants $\cdot \mathrm{m}^{-2}$ ) and frequency ${ }^{1}$ of seeded and nonseeded perennials, Bromus tectorum, and other annuals in five surveyed fire sites by 2010. Values are means, averaged across aspects; numbers in parentheses are standard errors. Letters represent significant $(P<0.05)$ differences based on Tukey's HSD within main effects. Perennial forbs were not seeded at two sites, indicated by dashes.

\begin{tabular}{|c|c|c|c|c|c|c|c|c|}
\hline & Site & $\begin{array}{l}\text { Seeded perennial } \\
\text { grasses }^{1}\end{array}$ & $\begin{array}{l}\text { Seeded perennial } \\
\text { forbs }^{2}\end{array}$ & $\begin{array}{l}\text { Nonseeded } \\
\text { perennial grasses }{ }^{1}\end{array}$ & $\begin{array}{c}\text { Nonseeded } \\
\text { perennial forbs }{ }^{1}\end{array}$ & $\begin{array}{l}\text { Nonseeded } \\
\text { shrubs }^{2}\end{array}$ & B. tectorum ${ }^{3}$ & Other annuals ${ }^{3}$ \\
\hline \multirow[t]{5}{*}{ Density in 2010} & Basco & $13.3(4.0) \mathrm{a}$ & $0.04(0.3) b$ & $40.8(8.4) \mathrm{a}$ & $12.3(1.7) \mathrm{ab}$ & $0.3(0.1) b$ & $829.4(172.1) b$ & $645.1(164.0) \mathrm{a}$ \\
\hline & East Humboldt & $5.7(0.4) b c$ & - & $1.5(0.9) \mathrm{c}$ & $1.5(0.9) \mathrm{c}$ & $0.6(0.1) a b$ & $55.0(32.9) \mathrm{C}$ & $424.1(102.1) \mathrm{a}$ \\
\hline & East Suzie & $4.8(0.5) \mathrm{bc}$ & $1.2(0.5) \mathrm{a}$ & $0.6(0.4) \mathrm{c}$ & $0.4(0.2) \mathrm{c}$ & $0.3(0.1) b$ & $64.2(13.6) \mathrm{c}$ & $1172.1(343.6) \mathrm{a}$ \\
\hline & Mudd & $2.2(0.7) \mathrm{c}$ & $0.2(0.1) a b$ & $10.0(1.8) b c$ & $16.7(2.2) \mathrm{a}$ & $1.8(0.8) \mathrm{a}$ & 1433.3 (207.4) ab & $1452.9(425.6) \mathrm{a}$ \\
\hline & Sneekee & $9.4(2.7) a b$ & - & $23.5(3.3) b$ & $9.6(1.7) \mathrm{b}$ & $0.3(0.1) b$ & $1543.1(240.5) \mathrm{a}$ & 809.8 (195.1) a \\
\hline \multirow[t]{5}{*}{ Frequency $^{1}$ in 2010} & Basco & $27.5(8.2) b$ & $1.9(1.9) \mathrm{b}$ & $84.3(5.8) \mathrm{a}$ & $72.5(7.1) a b$ & $23.5(7.4) \mathrm{a}$ & $70.6(9.0) a b$ & $86.3(4.1) \mathrm{a}$ \\
\hline & East Humboldt & $74.1(6.9) \mathrm{a}$ & - & $48.1(7.2) b$ & $13.0(3.9) \mathrm{c}$ & $38.9(8.6) \mathrm{a}$ & $11.1(4.7) \mathrm{C}$ & $48.1(7.7) \mathrm{C}$ \\
\hline & East Suzie & $63.5(5.3) \mathrm{a}$ & $16.1(5.7) \mathrm{a}$ & $8.2(4.7) \mathrm{c}$ & $9.0(3.3) \mathrm{c}$ & $19.6(7.6) \mathrm{a}$ & $60.4(9.1) b$ & $57.3(8.5)$ bc \\
\hline & Mudd & $23.5(6.2) b$ & $15.7(5.0) \mathrm{a}$ & $56.9(9.8) b$ & $74.5(6.1) \mathrm{a}$ & $21.6(6.4) \mathrm{a}$ & $86.3(5.6) \mathrm{a}$ & $92.2(3.5) \mathrm{a}$ \\
\hline & Sneekee & $29.4(8.0) b$ & - & 64.7 (8.3) ab & $52.9(11.1) b$ & $21.6(6.4) \mathrm{a}$ & $86.3(6.42)$ a & $70.6(6.3) a b$ \\
\hline
\end{tabular}

${ }^{1}$ Frequency measured in a $0.5 \times 0.5 \mathrm{~m}$ quadrat for seeded perennial grasses, nonseeded perennial grasses, and nonseeded perennial forbs.

${ }^{2} \mathrm{~A} 1 \times 1 \mathrm{~m}$ quadrat for seeded perennial forbs and nonseeded shrubs.

${ }^{3} \mathrm{~A} 0.1 \times 0.1 \mathrm{~m}$ quadrat for $B$. tectorum and other annuals.

densities across all aspects throughout the surveyed years (Fig. 2).

B. tectorum showed initially at low densities at all sites, but increased in different ways at different sites (Table 2, Fig. 2). Increased densities on south aspects were observed at the Basco and East Humboldt sites, and increased on the south aspects and flat areas at the Sneekee site over time. There was a notable decrease in B. tectorum density on south aspects and flat areas at the East Suzie site and on the south aspects of the Mudd site in 2010, where other invasive annuals were very common (Table 3). Further details of site-specific responses for seeded and nonseeded species by functional group are reported in Kulpa (2010).

Other annual species had initially low densities at the Mudd site $(19.6 \pm 10.8)$, intermediate densities at the Basco $(56.9 \pm 13.8)$ and Sneekee sites $(60.8 \pm 14.0)$, and the highest densities at East Humboldt $(117.6 \pm 30.7)$ and East Suzie $(120.7 \pm 25.5)$, but densities increased at all sites over time (Tables 2 and 3). The site by year by aspect interaction for these other annuals was due to the nature of these changes in specific sites: At the Basco and East Suzie sites, change was gradual and linear over time, and the Sneekee and Mudd sites maintained more consistent densities until 2010, when densities increased dramatically, especially on south aspects and flat areas (data not shown). The East Humboldt site had showed year-to-year fluctuations in other annual densities rather than a steady increase over time, with the greatest abundance in 2008 and 2010 (2007: 117.6 $\pm 30.7 ; 2008$ : 557.4 \pm 169.5 ; 2009: $311.1 \pm 41.9 ; 2010$ : $424.1 \pm 102.1)$. Regardless of the year, the East Humboldt site had consistently higher densities of other annuals on flat areas than on north or south aspects $\left(\mathrm{F}_{2,52}=15.0, P<0.0001\right.$; Flat: $650 \pm 124.0$; North: $177.8 \pm$ 71.1; South: 229.9 \pm 47.3).

Across all sites, the density of seeded species was highest in the year immediately following seeding and declined over time (Table 2). Densities of seeded perennial grasses were highest in 2007, declined in 2008, and remained similar through 2010 (Fig. 3A). Densities of seeded perennial forbs showed a similar trend, but did not differ among years $\left(\mathrm{F}_{3,162}=5.3, P=0.0017\right.$; 2007: $0.4 \pm 0.1 ; 2008: 0.1 \pm 0.01 ; 2009: 0.2 \pm 0.01 ; 2010$ :
$0.3 \pm 0.1)$. Seeded shrubs were never present at high densities (2007: $0.19 \pm 0.1 ; 2008$ : $0.16 \pm 0.1$ ) but declined to nearundetectable levels in $2009(0.07 \pm 0.01)$, and were not monitored in 2010. Nonseeded grasses maintained a mostly stable density across the sampling period, showing very similar densities in 2010 as in 2007, with a spike in abundance in 2008 (Fig. 3B). Nonseeded native perennial forbs and native shrubs also increased quickly between 2007 and 2008, but after that, densities did not change through 2010 (Fig. 3C and 3D). B. tectorum and other annual species also increased in density over time (Fig. 3E and 3F). B. tectorum increased between 2008 and 2009, with densities then remaining similar from 2009 and 2010 (Fig. 3E). The density of other annuals, which were primarily weedy species, increased steadily over the study periods, reaching their highest densities in 2010 (Fig. 3F). Cover data paralleled these results (Fig. 4), and in addition, demonstrated decreases in bare ground $\left(\mathrm{F}_{3,284}=42.1, P<\right.$ $0.0001)$ and increases in litter $\left(F_{3,284}=112.5, P<0.0001\right)$ over time.

Overall, nonseeded native vegetation, including grasses, forbs, and shrubs, had the highest densities on north aspects, and were least common on south aspects (Table 2, Fig. 3B-3D; nonseeded grasses $F_{2,9.1}=14.5, P=0.0015$; nonseeded forbs, $\mathrm{F}_{2,9.2}=9.5, P=0.0057$; nonseeded shrubs $\mathrm{F}_{2,8.7}=1.7, P=$ 0.2305). B. tectorum had the highest densities on south facing aspects, with, on average, more than twice the population densities on south aspects than on north aspects or in flat areas (Table 2, Fig. 3E). Other annuals were overall most dense on flat areas (Table 2, Fig. 3F). Flat areas and north aspects had higher frequencies of dead shrub stems than south aspects (Table 1).

Sites differed overall in the degree to which nonseeded perennial plants and $B$. tectorum dominated vegetation (Table 2). At the Basco, Mudd, and Sneekee sites, nonseeded perennial grasses, forbs, and shrubs had higher densities than seeded species, with nonseeded species making up $80 \%, 92 \%$, and $78 \%$ of the perennial plants in the sample area by 2010, respectively (Table 3). At the East Humboldt and East Suzie sites, the opposite was true, and there were relatively few nonseeded perennial species within these sites, making up only 

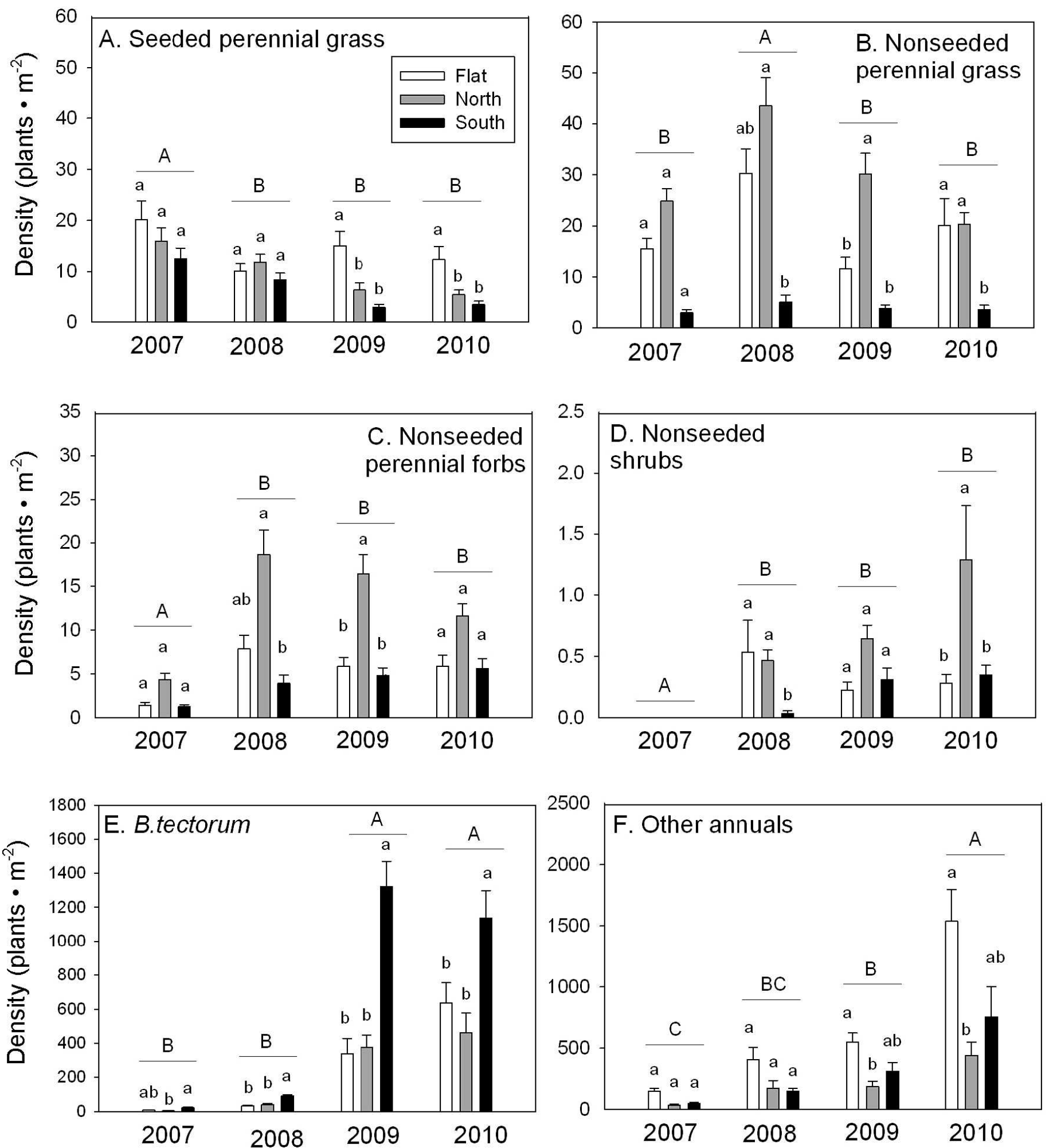

Figure 3. The density of A, seeded perennial grasses. B, nonseeded perennial grasses. C, nonseeded perennial forbs. D, nonseeded shrubs. E, Bromus tectorum. F, other annuals on flat areas, north aspects, and south aspects, from 2007 to 2010. Values are means and standard errors averaged across all sites. Upper-case letters indicate differences among years based on Tukey's tests; lower-case letters indicate significant differences among aspects within years. 


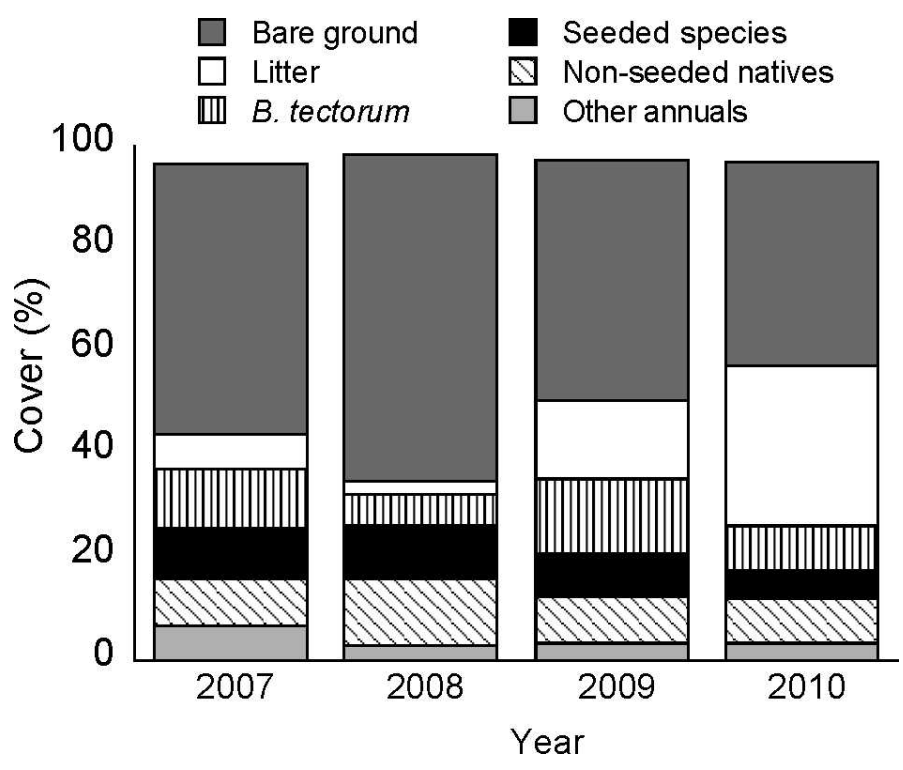

Figure 4. Change in aerial cover from 2007 to 2010, averaged across all five sites. Seeded species are primarily perennial grasses, but forb and shrub cover are included in these measures. Nonseeded native species included a mix of perennial grasses, forbs, and shrubs; "other annuals" are almost entirely weedy forbs. Cover values of rocks and dead shrub stems were minor and not included in this figure; therefore, values do not add up to $100 \%$.

$39 \%$ and $18 \%$ of the respective perennial plant community in 2010 (Table 3). The density objectives for seeded perennial grass (three established plants $\mathrm{m}^{-2}$ ) were met at all but the Mudd site by the fourth year of monitoring (Table 3). Seeded perennial forbs and shrubs did not make up a large component of the established community at any site (Table 3 ).

By 2010, the presence of B. tectorum was lowest at the East Humboldt and East Suzie sites, followed by Basco, and highest at the Sneekee and Mudd sites (Table 3). Densities of other annuals were not different among sites (Table 3). The most common annual present at the East Humboldt site was the nonnative species Ceratocephala testiculata Crantz (Roth) (burr buttercup). At the East Suzie and Mudd sites, annual weedy mustard species were extremely common, and at East
Suzie the thistle O. acanthium (either an annual or a biennial, but counted as an annual in our surveys for simplicity) was also common.

Cover of plant categories in 2010 was different (all $P<0.0015)$ between sites for seeded perennial grasses, nonseeded perennial grasses and forbs, and B. tectorum, with results generally corresponding with density counts. Additionally, sites differed in the amount of bare ground $\left(\mathrm{F}_{4,71}=17.9\right.$, $P<0.0001)$ and litter $\left(\mathrm{F}_{4,71}=4.2, P=0.0041\right)$. East Humboldt had the highest percentage of bare ground $(63 \pm 2.7 \%)$ relative to the other fire sites, and the Mudd site had the lowest $(26 \pm 5.1 \%)$. Sneekee had higher litter cover $(44 \pm 4.3 \%)$ than the other sites, where litter cover varied between $25 \%$ and $29 \%$.

Vegetation changed more quickly on some aspects than on others, for all categories (year $\times$ aspect interaction, Table 2). The largest differences in community composition among different aspects were generally observed 2 or more years following the fire. For example, differences in the density of seeded perennial grasses across aspects were not significant in 2007 or 2008, but by 2009 and 2010 establishment on flat areas was higher than on north and south aspects $\left(\mathrm{F}_{6,247.7}=3.8, \quad P=0.0037\right.$, Fig. 3A). Nonseeded perennial grasses had overall higher densities on north aspects and flat areas than on south aspects for all surveyed years, with the strongest differences observed in 2009 and $2010\left(\mathrm{~F}_{6,247.1}=4.3\right.$, $P=0.0004$, Fig. 3B). Nonseeded perennial forbs showed a similar pattern, with the highest densities on north aspects, with this difference significant in $2009\left(\mathrm{~F}_{6,250.1}=5.9\right.$, $P<0.0001$, Fig. 3C). Nonseeded shrubs increased in density on north aspects through 2010, when the largest differences were observed $\left(\mathrm{F}_{6,248.8}=2.6, P=0.0179\right.$, Fig. $\left.3 \mathrm{D}\right)$.

$B$. tectorum showed the most dramatic changes in density among aspects over time (Table 2, Fig. 3E). The increase in $B$. tectorum density through 2009 and 2010 was especially large on south aspects, with densities increasing on flat and north aspects as well, though to a lesser degree (Fig. 3E). Other annuals did not show strong differentiation in densities between aspects until 2009 and 2010, when densities increased dramatically in flat areas, and to a lesser degree, south aspects (Table 2, Fig. 3F).

Table 4. Degree to which frequency data predicted density data, by species or vegetation category, for the 4-yr survey period. Nonseeded shrubs were extremely rare in 2007, as were seeded shrubs in 2010; therefore, these values were not analyzed, indicated with dashes.

\begin{tabular}{|c|c|c|c|c|}
\hline & 2007 & 2008 & 2009 & 2010 \\
\hline Category & $R^{2}$ & $R^{2}$ & $R^{2}$ & $R^{2}$ \\
\hline Seeded perennial grass & $0.79 * * *$ & $0.53^{\star * *}$ & $0.65^{\star \star *}$ & $0.60^{*}$ \\
\hline Nonseeded perennial grass & $0.55^{\star *}$ & $0.73^{\star * *}$ & $0.82^{* * *}$ & $0.87^{\star \star \star}$ \\
\hline Bromus tectorum & $0.84^{* * *}$ & $0.79^{* * *}$ & $0.80^{* * *}$ & $0.81^{\star * *}$ \\
\hline Other annuals & $0.38^{\star *}$ & $0.47^{\star * *}$ & $0.58^{* * *}$ & $0.76^{\star \star}$ \\
\hline Seeded perennial forb & $0.90^{* * *}$ & $0.98^{\star * *}$ & $0.99 * * *$ & $0.99^{\star * *}$ \\
\hline Nonseeded perennial forb & $0.66^{\star * *}$ & $0.77^{\star * *}$ & $0.87^{* * *}$ & $0.92^{\star \star \star}$ \\
\hline Seeded shrub & $0.94^{\star * *}$ & $0.68^{* * *}$ & $0.84^{\star *}$ & - \\
\hline Nonseeded shrub & - & $0.74^{\star \star \star}$ & $0.94^{* * *}$ & $0.95^{\star \star *}$ \\
\hline
\end{tabular}

${ }^{\star} P<0.05$.

${ }^{* *} P<0.001$.

$\star * * P<0.0001$ 
Relationship Between Frequency and Density Measurements Results of frequency measures were related to density measures for all vegetation categories (Table 4), though the predictive power of this relationship varied among categories and across years. Agreement between density and frequency data was strongest overall in 2010, when $R^{2}$ values were greater than 0.76 for six out of the seven vegetation categories. The strength of the predictive relationship for seeded perennial grasses was strongest in the year following fire, and thereafter was one of the weaker relationships (Table 4). The density of other annuals was not well predicted by frequency measures until 2010. Most frequency patterns were similar in magnitude, if not significance, to those of the density analysis, especially when comparing abundance across aspects and between years (data not shown, see Kulpa 2010), and sites maintained their relative rank in most categories, regardless of whether frequency or density measures are compared (Table 3). A notable exception was seeded perennial grasses, which, though they decreased significantly in density over time, did not decrease significantly in frequency over time (presence over time in the $0.5 \times 0.5 \mathrm{~m}$ quadrat, 2007: 35.5 $\pm 6.9 ; 2008$ : 52.2 $\pm 5.4 ; 2009: 40.3 \pm 6.1 ; 2010: 43.4 \pm 6.2$ ) and showed different patterns of establishment when comparing among sites (Table 3).

\section{DISCUSSION}

Postfire seeding is a common management practice in western US rangelands, undertaken with the goals of restoring perennial, usually native, plant communities and minimizing negative impacts by exotic species. At our study sites, the community composition changed considerably over the $4 \mathrm{yr}$ of study, with time since fire and aspect having strong influences on the recovery process. Sites differed from each other in their specific recovery patterns, but there were some general patterns that emerged. Seeded species, especially rhizomatous grasses, were most likely to establish in flat areas, whereas other seeded species decreased in density over time. Nonseeded native species had highest densities on north aspects and flat areas, and either maintained stable densities (native perennial grasses) or increased (forbs and shrubs) over the 4-yr period. $B$. tectorum abundance increased more rapidly than any other vegetation category, particularly on south aspects, except in some areas where the densities of exotic annual forbs were very common. Our data are consistent with the observation that even if $B$. tectorum seedbanks are depleted by fires, rapid reproduction can increase population densities and litter accumulation very quickly, increasing the potential for fire recurrence (D'Antonio and Vitousek 1992; Humphrey and Schupp 2001).

Nonseeded plants made up a large proportion of perennial postfire vegetation in three of our study sites, despite the increase of $B$. tectorum over the same time period. This is consistent with other studies of postfire seeding in arid rangelands, where resprouting native plants can be very common in seeded areas, even more so than seeded species (Keeley et al. 1995; Ratzlaff and Anderson 1995). For example, Pyke et al. (2003) found that nearly two-thirds of native plant composition on postfire revegetation sites in the Great Basin came from unsown species. Similar results were seen in four experimentally seeded fires in eastern Oregon, where native, nonseeded vegetation recovered well after fire and made up a larger proportion of postfire vegetation than seeded species (James and Svejcar 2010), and in central Nevada, where postfire plant density did not differ between aerially seeded areas and nonseeded areas (Bruce et al. 2007). Nonseeded areas can recover better than seeded ones in some situations, possibly due to negative effects of disturbance associated with rehabilitation efforts (e.g., Ratzlaff and Anderson 1995). We did not have nonseeded control areas as part of our experimental design, which precludes analysis of the effects of rehabilitation efforts on resprouting native perennial grasses. Similarly, grazing was not manipulated in our experimental design, and the reintroduction of livestock to these sites in 2010 may affect community composition, though these effects could not be determined in this study.

Differences in recovery patterns among our sites are also due to differences in prefire vegetation condition, which may be critical to understanding how vegetation recovers after a fire (Monsen and McArthur 1984; Wirth and Pyke 2009). At small scales, native recovery is positively related to the density of native plants present at the time of fire (Chambers et al. 2007), and this is also reflected in larger- scale surveys. For example, in a study of 60 seeded fire sites in Winnemucca, Nevada, densities of seeded grasses and seeded forbs were higher at locations where the preburn vegetation included shrubs and was not a monoculture of annual grasses (Eiswerth et al. 2009). Fires in monocultures of annual grasses burn at cooler temperatures than fires in shrub communities, which can preclude native plant recovery because of unburned annual grass seeds and litter, in addition to sparse perennial-plant seed banks (Young et al. 1976; Humphrey and Schupp 2001). In this study, detailed data on prefire site condition was not available, so we used the frequency of dead shrub stems as a proxy to aid in preburn site characterization. Flat areas and north aspects had higher frequencies of dead shrub stems (Table 1), and this is also where we observed the most native species (Fig. 2B-2D). Across all surveyed flat areas, north aspects, and south aspects, the Basco and Sneekee sites had the highest frequency of dead shrub stems as well as the high densities of nonseeded perennial grasses and forbs. This supports the hypothesis that postfire recovery of native species is better when shrubs are present prefire.

In our sites, there was lower establishment of seeded species in fire sites when there were many nonseeded native plants. For example, seeded grass frequencies were the lowest at the Basco, Mudd, and Sneekee sites, which all had a large component of nonseeded vegetation, and highest at the East Humboldt and East Suzie sites, which had the lowest densities of nonseeded species. It is likely that competition with established native vegetation lowered the successful recruitment of seedlings in three of these sites. Finally, seed mix is a factor that can affect site recovery. Because seed mix differed from fire to fire, we were unable to account for the effect of this factor on site recovery. Only one of our sites, East Humboldt, was seeded solely with nonnative grasses, which are specifically selected for use in rangeland restorations because they are competitive with B. tectorum, but they are also competitive with Great Basin native species (Cox and Anderson 2004; Hulet et al. 2010). As 
might be expected, this site had low densities of B. tectorum, the greatest amount of bare ground, and the lowest plant diversity of all five sites, even $4 \mathrm{yr}$ after fire (Table 3).

Collecting frequency data is faster than gathering density data and may be an effective way to monitor larger areas with less effort (Elzinga et al. 1998). In this study, frequency data almost always gave similar results to our density data, and was particularly well suited for monitoring changes in the leastdense vegetation components, like perennial forbs and shrubs (Table 4). Frequency observations did not correlate as well with density measures for other categories, including $B$. tectorum, other annuals, and seeded grasses, all of which may have patchy distributions. For example, differences observed between frequency and density results for seeded perennial grasses (Table 3) may have been due to a combination of factors, including the rhizomatous nature of some of the seeded species, which can lead to very high localized densities even if plants are not common across the landscape, and to natural seedling establishment dynamics such as self-thinning. Selfthinning of even-aged plant populations is a natural process that begins when individuals begin to compete for resources (Westoby 1984; Pyke and Archer 1991), and is not unexpected following a seeding, especially when initial establishment densities are on the order of 16 plants $\mathrm{m}^{-2}$. Although similar conclusions about site condition may be drawn from these frequency and density measures early on in site recovery, it is important to note that the lack of sensitivity to decreasing densities inherent in frequency measurements might become detrimental if frequency measurements were used for longerterm monitoring.

\section{IMPLICATIONS}

Our results indicate that there are opportunities to increase efficiency and success of postfire recovery efforts. This study suggests that seeding efforts focused on south aspects and flat areas will have the greatest benefit, as south aspects are much more likely to be converted into a monoculture of B. tectorum, and seeded species are more likely to establish in flat areas. Managing south aspects and flat areas intensively could reduce the overall $B$. tectorum seed production within a fire, benefiting all other features of the landscape. On north aspects and flat areas in sites that had a prefire community with a large shrub component, we found that native vegetation was capable of recovering without seeding. The recovery may have been greater in these areas if left unseeded and undisturbed (e.g., Keeley et al. 1995; Beyers 2004). We have additionally provided analyses that quantify the degree to which frequency and density measures correlate for different vegetation categories. Further studies should be conducted to address under what circumstances frequency data are adequate to make conclusions about postfire recovery.

Our results suggest that there are opportunities for future research to improve the postfire recovery of these sites. In particular, new methods may need to be developed in order to achieve successful revegetation of south aspects, and trials could focus on testing factors such as seeding rate, seeding method, species composition, and/or herbicide use to improve establishment. Additionally, although resident native plants recovered in some areas, B. tectorum still increased, indicating that successful rehabilitation will require specific management to reduce weed abundance. Although the first postfire season is typically considered critical for establishing perennial vegetation and excluding weeds in arid systems, our data indicate that an additional opportunity may exist for intervention two seasons after a fire, when perennial grass densities are relatively high, perennial shrubs and forbs are recruiting, and B. tectorum densities are still relatively low (Fig. 2). Any action that could reduce the seed output of $B$. tectorum in the second growing season may favorably alter the course of community recovery over time.

\section{ACKNOWLEDGMENTS}

The authors would like to thank Tom Warren and Mark Coca, Elko Field Office, Bureau of Land Management, for providing seeding information and monitoring permission. We thank Taraneh Emam, Sandra Li, and Allison Phillips for assistance with fieldwork and Bob Blank and Tye Morgan for use and assistance at the USDA Forest Service Soils Lab, Reno, Nevada. We thank Bob Nowak, Sherm Swanson, and Mike Teglas, University of Nevada, Reno, Nevada, for offering editorial guidance and suggestions for this manuscript, and three anonymous reviewers for their contributions.

\section{LITERATURE CITED}

Abella, S. R., and W. W. Covington. 2004. Monitoring an Arizona ponderosa pine restoration: sampling efficiency and multivariate analysis of understory vegetation. Restoration Ecology 12:359-367.

Allen, E. B. 1995. Restoration ecology: limits and possibilities in arid and semiarid lands. In: B. A. Roundy, E. D. McArthur, J. S. Haley, And D. K. Mann [TECH. CooRDs.]. 1995. Proceedings of the Wildland Shrub and Arid Land Restoration Symposium. Ogden, UT: US Forest Service. General Technical Report INTGTR-315. p. 7-15.

Bennie, J., M. Hill, R. Baxter, and B. Huntley. 2006. Influence of slope and aspect on long-term vegetation change in British chalk grasslands. Journal of Ecology 94:355-368.

BEYERS, J. L. 2004. Postfire seeding for erosion control: effectiveness and impacts on native plant communities. Conservation Biology 18:947-956.

Bleak, A. T., N. C. Frischknecht, A. P. Plummer, and R. E. Eckert. 1965. Problems in artificial and natural revegetation of the arid shadscale vegetation zone of Utah and Nevada. Journal of Range Management 18:59-65.

Bochet, E., and P. García-Fayos. 2004. Factors controlling vegetation establishment and water erosion on motorway slopes in Valencia, Spain. Restoration Ecology 12:166-174.

Bonham, C. D. 1989. Measurements for terrestrial vegetation. New York, NY, USA: John Wiley and Sons. 338 p.

BRooks, M. L., AND D. A. PYKE. 2002. Invasive plants and fire in the deserts of North America. In: K. E. Galley and T. P. Wilson [EDS.]. Proceedings of the Invasive Species Workshop-The Role of Fire in the Control and Spread of Invasive Species. Fire Conference 2000-The First National Congress on Fire Ecology, Prevention, and Management. Tallahassee, FL, USA: Tall Timbers Research Station. Misc. Publication No. 11. p. 1-14.

Bruce, L. B., Perryman, B., Conley, K., And K. McAdoo. 2007. Case study: grazing management on seeded and unseeded post-fire public rangelands. The Professional Animal Scientist 23:285-290.

Burton, C. M., P. J. Burton, R. Hebda, and N. J. Turner. 2006. Determining the optimal sowing density for a mixture of native plants used to revegetate degraded ecosystems. Restoration Ecology 14:379-390.

Call, C. A., And B. A. Roundy. 1991. Perspectives and processes in revegetation of arid and semiarid rangelands. Journal of Range Management 44:543-549. 
Chambers, J. C., B. A. Roundy, R. R. Blank, S. E. Meyer, and A. Whittaker. 2007. What makes Great Basin sagebrush ecosystems invasible by Bromus tectorum? Ecological Monographs 77:117-145.

Cox, R. D., And V. J. Anderson. 2004. Increasing native diversity of cheatgrassdominated rangeland through assisted succession. Journal of Range Management 57:203-210.

D’Antonio, C. M., And P. M. Vitousek. 1992. Biological invasions by exotic grasses, the grass/fire cycle, and global change. Annual Review of Ecology and Systematics 23:63-87.

DiTomaso, J. M. 2000. Invasive weeds in rangelands: species, impacts, and management. Weed Science 48:255-265.

Eiswerth, M. E., K. Krauter, S. R. Swanson, and M. Zielinski. 2009. Post-fire seeding on Wyoming big sagebrush ecological sites: regression analyses of seeded nonnative and native species densities. Journal of Environmental Management 90:1320-1325.

EISWERTH, M. E., AND J. S. SHONKWILER. 2006. Examining post-wildfire reseeding on arid rangeland: a multivariate tobit modeling approach. Ecological Modeling 192:286-298.

Elzinga, C. L., D. W. Salzer, and J. W. Willoughby. 1998. Measuring and monitoring plant populations. Denver, CO: US Department of the Interior, Bureau of Land Management, National Business Center. Technical Reference 1730-1. 477 p.

Gong, J., L. D. Chen, B. J. Fu, And W. Wei. 2007. Integrated effects of slope aspect and land use on soil nutrients in a small catchment in a hilly loess area, China. International Journal of Sustainable Development and World Ecology 14:307-316.

Hulet, A., B. A. Roundy, And B. Jessop. 2010. Crested wheatgrass control and native plant establishment in Utah. Rangeland Ecology \& Management 63:450-460.

Humphrey, D. L., and E. W. Schupp. 2001. Seed banks of Bromus tectorumdominated communities in the Great Basin. Western North American Naturalist 61:85-92.

JAMES, J. J., AND T. SVEJCAR. 2010. Limitations to postfire seedling establishment: the role of seeding technology, water availability, and invasive plant abundance. Rangeland Ecology \& Management 63:491-495.

Keeley, J. E., M. Carrington, and S. Trnka. 1995. Overview of management issues raised by the 1993 wildfires in southern California. In: J. E. Keeley and T. Scott [EDS.]. Brushfires in California wildlands: ecology and resource management. Fairfield, WA, USA: International Association of Wildland Fire. p. 83-89.

Knutson, K. C., D. A. Pyke, T. A. Wirth, D. S. Pilliod, M. L. Brooks, and J. C. Chambers. 2009. A chronosequence feasibility assessment of emergency fire rehabilitation records within the intermountain western United States-final report to the Joint Fire Science Program Project 08-S-08. Reston, VA: US Geological Survey. Open File Report 2009-1099. 20 p.

KonIAK, S. 1985. Succession in pinyon-juniper woodlands following wildfire in the Great Basin. Great Basin Naturalist 45:556-566.

Korb, J. E., W. W. Covington, and P. Z. Fule. 2003. Sampling techniques influence understory plant trajectories after restoration: an example from ponderosa pine restoration. Restoration Ecology 11:504-515.

KULPA, S. M. 2010. Identifying barriers to successful establishment of post-fire seeding in the Great Basin. Reno, NV, USA: University of Nevada, Reno. $116 \mathrm{p}$.

KutIEL, P. 1992. Slope aspect effect on soil and vegetation in a Mediterranean ecosystem. Israel Journal of Botany 41:243-250.

Marlon, J. R., P. J. Bartlein, M. K. Walsh, S. P. Harrison, K. J. Brown, M. E. Edwards, P. E. Higuera, M. J. Power, R. S. Anderson, C. Briles, A. Brunelle, C. Carcalllet, M. Daniels, F. S. Hu, M. Lavoie, C. Long, T. Minckley, P. J. H. Richard, A. C. Scott, D. S. Shafer, W. Tinner, C. E. Umbanhowar, and C. Whitlock. 2009. Wildfire responses to abrupt climate change in North America. Proceedings of the National Academy of Sciences of the United States of America 106:2519-2524.

Miller, R. F., AND J. A. Rose. 1999. Fire history and western juniper encroachment in sagebrush steppe. Journal of Range Management 52:550-559.

MıLton, S. J. 2004. Grasses as invasive alien plants in South Africa. South African Journal of Science 100:69-75.

Monsen, S. B., AND E. D. McArthur. 1984. Factors influencing establishment of seeded broadleaf herbs and shrubs following fire. In: K. D. Sanders and J. Durham [EDS.]. Rangeland Fire Effects: A Symposium. Proceedings of a
Symposium Sponsored by Bureau of Land Management and University of Idaho; 27-29 November 1984; Boise, ID, USA. Boise, ID, USA: Bureau of Land Management and the University of Idaho. p. 112-124.

Montalvo, A. M., P. A. McMillan, and E. B. Allen. 2002. The relative importance of seeding method, soil ripping, and soil variables on seeding success. Restoration Ecology 10:52-67.

Pyke, D. A., T. 0. McArthur, K. S. Harrison, and M. Pellant. 2003. Coordinated Intermountain Restoration Project-fire, decomposition, and restoration. In: N. Allsopp and N. Walker [EDS.]. Proceedings of the VII International Rangeland Congress; 28 July-1 August 2003; Durban, South Africa. Durban, South Africa: International Rangeland Congress. p. 1116-1124.

PyKE, D. A., AND S. ARCHeR. 1991. Plant-plant interactions affecting plant establishment and persistence on revegetated rangeland. Journal of Range Management 44:550-557.

Pyke, D. A., And T. O. McArthuR. 2002. Emergency fire rehabilitation of BLM lands in the Intermountain West: Revegetation \& monitoring. Corvallis, OR, USA: USGS Forest \& Rangeland Ecosystem Science Center. Interim report to the BLM.

RatzlafF, T. D., AND J. E. Anderson. 1995. Vegetal recovery following wildfire in seeded and unseeded sagebrush steppe. Journal of Range Management 48:386-391.

Rech, J. A., R. W. ReEves, And D. M. Hendricks. 2001. The influence of slope aspect on soil weathering processes in the Springerville volcanic field, Arizona. Catena 43:49-62.

Robichaud, P. R., J. L. Beyers, and D. G. Neary. 2000. Evaluating the effectiveness of post-fire rehabilitation treatments. Fort Collins, CO, USA: USDA Forest Service, Rocky Mountain Research Station. General Technical Report RMRSGTR-63. $85 \mathrm{p}$.

SAS InSTITUTE Inc. 2009. JMP 8 user guide. 2nd ed. Cary, NC, USA: SAS Institute Inc.

Shinneman, D. J., AND W. L. Baker. 2009. Environmental and climatic variables as potential drivers of post-fire cover of cheatgrass (Bromus tectorum) in seeded and unseeded semiarid ecosystems. International Journal of Wildland Fire 18:191-202.

Sternberg, M., and M. Shoshany. 2001. Influence of slope aspect on Mediterranean woody formations: comparison of semiarid and an arid site in Israel. Ecological Research 16:335-345.

Thompson, T. W., B. A. Roundy, E. D. McArthur, B. D. Jessop, B. Waldron, and J. N. Davis. 2006. Fire rehabilitation using native and introduced species: a landscape trial. Rangeland Ecology \& Management 59:237-248.

us Department of the Interior, Bureau of Land Management. 2007. Burned area emergency stabilization and rehabilitation handbook (public). Washington, DC, USA: US Department of the Interior, Bureau of Land Management. Manual Handbook H-1742-1.

Vogel, K. P., and R. A. Masters. 2001. Frequency grid-a simple tool for measuring grassland establishment. Journal of Range Management 54:653-655.

West, N. E., AND M. A. Hassan. 1985. Recovery of sagebrush-grass vegetation following wildfire. Journal of Range Management 38:131-134.

Westerling, A. L., H. G. Hidalgo, D. R. Cayan, and T. W. Swetnam. 2006. Warming and earlier spring increase western US forest wildfire activity. Science 313:940-943.

Westoby, M. 1984. The self-thinning rule. Advances in Ecological Research 14:167-225.

WiRTh, T. A., AND D. A. PyKe. 2007. Monitoring post-fire vegetation rehabilitation projects-A common approach for non-forested ecosystems. Reston, VA, USA: US Geological Survey. Scientific Investigations Report 2006-5048. 36 p.

WiRTh, T. A., AND D. A. PYKE. 2009. Final report for emergency stabilization and rehabilitation treatment monitoring of the Keeney Pass, Cow Hollow, Double Mountain, and Farewell Bend fires. Reston, VA, USA: US Geological Survey. Open File Report 2009-1152. 62 p.

Young, J. A., and F. L. Allen. 1997. Cheatgrass and range science: 1930-1950. Journal of Range Management 50:530-535.

Young, J. A., And R. A. Evans. 1978. Population dynamics after wildfires in sagebrush grasslands. Journal of Range Management 31:283-289.

Young, J. A., R. A. Evans, and R. A. Weaver. 1976. Estimating potential downy brome competition after wildfire. Journal of Range Management 29:322-325. 